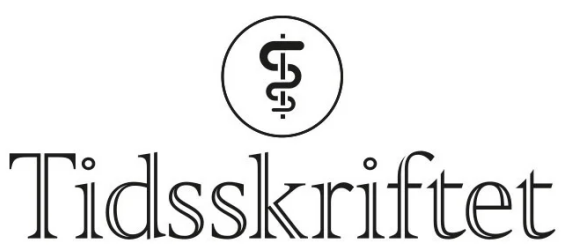

\title{
Reversering av antikoagulerende legemidler ved hjerneblødning
}

KLINISK OVERSIKT

\section{HÅKON IHLE-HANSEN}

haaihl@vestreviken.no

Seksjon for geriatri, slag og rehabilitering

Bærum sykehus

Vestre Viken

Han har bidratt med idé, førsteutkast og utarbeiding/revisjon av manus, litteratursøk og godkjenning av innsendte manusversjon.

Håkon Ihle-Hansen er ph.d. og konstituert overlege.

Forfatteren har fylt ut ICMJE-skjemaet og oppgir ingen interessekonflikter.

\section{GURI HAGBERG}

Seksjon for hjerneslag

Oslo universitetssykehus, Ullevål

Hun har bidratt med idé, utarbeiding/revisjon av manus, litteratursøk og godkjenning av innsendte manusversjon.

Guri Hagberg er ph.d., spesialist i indremedisin og i geriatri og overlege.

Forfatteren har fylt ut ICMJE-skjemaet og oppgir ingen interessekonflikter.

\section{ELSE CHARLOTTE SANDSET}

Seksjon for hjerneslag

Oslo universitetssykehus, Ullevål

Hun har bidratt med idé, utarbeiding/revisjon av manus, litteratursøk og godkjenning av innsendte manusversjon.

Else Charlotte Sandset er ph.d., spesialist i nevrologi og overlege.

Forfatteren har fylt ut ICMJE-skjemaet og oppgir følgende interessekonflikter: Avdelingen har mottatt penger fra Portola for hennes arbeid som nasjonal koordinator for ANNEXA 4-studien.

\section{HEGE IHLE-HANSEN}

Seksjon for hjerneslag

Oslo universitetssykehus, Ullevål

Hun har bidratt med idé, utarbeiding/revisjon av manus, litteratursøk og godkjenning av innsendte manusversjon.

Hege Ihle-Hansen er ph.d., spesialist i indremedisin og i geriatri og seksjonsleder. Forfatteren har fylt ut ICMJE-skjemaet og oppgir ingen interessekonflikter.

\section{ERIK KOLDBERG AMUNDSEN}

Avdeling for medisinsk biokjemi

Oslo universitetssykehus 
Han har bidratt med utarbeiding/revisjon av manus, litteratursøk og godkjenning av innsendte manusversjon.

Erik Koldberg Amundsen er ph.d. og overlege i medisinsk biokjemi.

Forfatteren har fylt ut ICMJE-skjemaet og oppgir ingen interessekonflikter.

\section{PER MORTEN SANDSET}

Universitetet i Oslo

og

Oslo universitetssykehus, Rikshospitalet

Han har bidratt med utarbeiding/revisjon av manus, litteraturs $\emptyset \mathrm{k}$ og godkjenning av innsendte manusversjon.

Per Morten Sandset er spesialist i indremedisin og i hematologi, viserektor og professor og overlege. Forfatteren har fylt ut ICMJE-skjemaet og oppgir ingen interessekonflikter.

\section{MARIUS MYRSTAD}

Seksjon for geriatri, slag og rehabilitering

og

Forskningsavdelingen

Bærum sykehus

Vestre Viken

Han har bidratt med førsteutkast og utarbeiding/revisjon av manus, litteratursøk og godkjenning av innsendte manusversjon.

Marius Myrstad er ph.d., spesialist i indremedisin og i geriatri, overlege og postdoktor/forsker.

Forfatteren har fylt ut ICMJE-skjemaet og oppgir ingen interessekonflikter.

\section{Antikoagulerende legemidler kan effektivt forebygge og behandle blodpropper, men gir samtidig $\varnothing \mathrm{kt}$ risiko for hjerneblødning. Ved hjerneblødning anbefales rask reversering av den antikoagulerende effekten. Reverserende behandling må imidlertid velges ut ifra antikoagulasjonsmidlenes ulike virkningsmekanismer, og spesifikk antidot foretrekkes hvis tilgjengelig.}

$\emptyset \mathrm{kt}$ bruk av antikoagulerende legemidler har medført $\varnothing \mathrm{kt}$ forekomst av hjerneblødninger $(\underline{1}, \underline{2})$. Antikoagulerende legemidler gir en årlig risiko for hjerneblødning på o,1-0,6 \% (3) og forårsaker hvert år rundt 350 hjerneblødninger i Norge (4.). Disse legemidlene brukes blant annet for å forebygge blodpropp ved atrieflimmer og ved mekanisk hjerteventil og til behandling av arteriell og venøs tromboembolisk sykdom.

Rundt 140 ooo nordmenn har atrieflimmer (5). Denne tilstanden gir risiko for emboliske hjerneinfarkter $(\underline{6})$, som er den hyppigste indikasjonen for antikoagulasjonsbehandling (7.). Mest brukt i dag er direktevirkende perorale antikoagulasjonsmidler (DOAK), etterfulgt av hepariner og warfarin (요).

Hjerneblødning er en alvorlig tilstand med høy dødelighet (9.), der tidlig

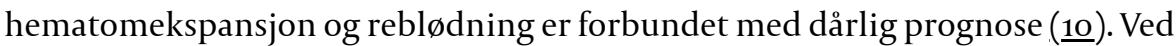
hjerneblødning under pågående antikoagulasjonsbehandling kan rask reversering av den antikoagulerende effekten trolig redusere hematomvekst og risiko for ny blødning. Det er ikke godt undersøkt om reverserende behandling også kan bedre det kliniske utfallet, men det er etter internasjonal konsensus anbefalt å reversere effekten av antikoagulerende legemidler ved akutte hjerneblødninger (7,프). Da de ulike antikoagulerende legemidlene har ulike virkningsmekanismer, vil reverserende behandling variere avhengig av hvilket legemiddel pasienten bruker. Tilgang på nye legemidler de siste ti årene har gjort fagfeltet mer uoversiktlig. 
Vi gir her en oversikt over kunnskapsgrunnlaget for reverserende behandling av antikoagulerende legemidler ved hjerneblødning og forslag til praktisk tilnærming $\mathrm{i}$ akuttsituasjoner, tilpasset norske forhold. Artikkelen er basert på et skjønnsmessig litteraturutvalg og forfatternes kliniske erfaring.

\section{Reverserende behandling}

Akuttbehandling ved påvist hjerneblødning inkluderer blodtrykksbehandling og dialog med nevrokirurg rundt potensielle intervensjoner og rask reversering av antikoagulerende legemidler. Tilgjengelige antikoagulerende medikamenter i Norge, tilhørende reverserende legemidler (tabell 1) og deres virkningsmekanismer (figur 1) vil gjennomgås systematisk.

\section{Tabell 1}

Oversikt over tilgjengelige antikoagulerende medikamenter i henhold til Felleskatalogen (2021) og tilhørende reverserende legemidler. DOAK = direktevirkende perorale antikoagulasjonsmidler

\begin{tabular}{|cll|}
\hline \multicolumn{2}{|c|}{ Antikoagulerende legemiddel } & Reverserende legemiddel \\
\hline Perorale midler & & \\
\hline Vitamin K-antagonister & $\begin{array}{l}\text { Warfarin (Marevan/Warfarin } \\
\text { Orio) }\end{array}$ & $\begin{array}{l}\text { Protrombinkompleks } \\
\text { (Octaplex, Prothromplex, } \\
\text { Confidex) og Vitamin K } \\
\text { (Konakion) }\end{array}$ \\
\hline DOAK-midler & & \\
\hline Trombin (Ila)-hemmer & Dabigatran (Pradaxa) & $\begin{array}{l}\text { Idarusizumab (Praxbind), } \\
\text { alternativt } \\
\text { protrombinkompleks }\end{array}$ \\
\hline Faktor Xa-hemmer & Apiksaban (Eliquis) & $\begin{array}{l}\text { Protrombinkompleks, } \\
\text { Andeksanet alfa (Ondexxya), } \\
\text { foreløpig ikke tilgjengelig i } \\
\end{array}$ \\
& Rivaroksaban (Xarelto) & Norge \\
\hline Parenterale midler & Heparin & Protamin (Protaminsulfat) \\
\hline Ufraksjonert heparin & Dalteparin (Fragmin) & Protamin (Protaminsulfat) \\
\hline Lavmolekylære hepariner & Enoksaprin (Klexane) & \\
\hline
\end{tabular}




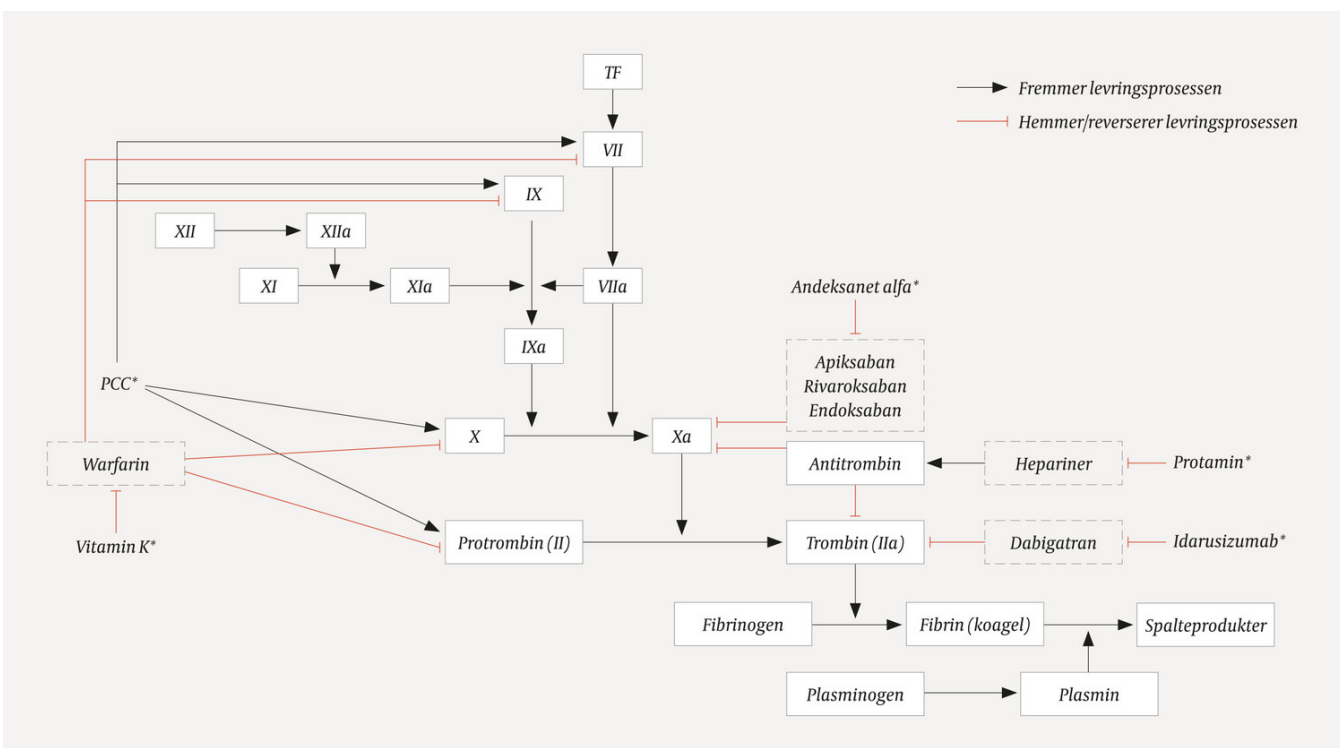

Figur 1 Koagulasjonssystemet med angrepspunktene til ulike antikoagulerende legemidler og mulige reverserende legemidler $\left(\right.$ merket $\left.^{*}\right)$. TF = vevsfaktor (tissue factor), PPC = protrombinkompleks.

VITAMIN K-ANTAGONISTER

Virkningen av warfarin (Marevan, Warfarin Orion) kan raskt reverseres ved hjelp av protrombinkompleks (Octaplex, Prothromplex, Confidex) eller ferskfrosset plasma (므).

Protrombinkompleks foretrekkes fremfor ferskfrosset plasma, da protrombinkompleks har en sterkere reversering av antikoagulasjonseffekten og bedre evne til å forhindre hematomekspansjon enn ferskfrosset plasma, men det er ikke vist forskjell på pasientens funksjonsevne eller mortalitet etter tre måneder (13).

Protrombinkompleks inneholder koagulasjonsfaktorene som hemmes av warfarin (II, VII, IX $\operatorname{og} \mathrm{X})$ (14), og adekvat dosering gir umiddelbar og full reversering av antikoagulasjonseffekten.

Dosen av protrombinkompleks som kreves for å reversere virkningen av vitamin Kantagonister, er avhengig av INR-nivå (14.), men én dose på zo IE/kg vil være tilstrekkelig selv ved høye INR-verdier (13). Ved protrombinkompleks kan det komme en INR-stigning 12-24 timer etter infusjon, som skyldes vedvarende warfarineffekt (halveringstid 32 timer) (15). 5-10 mg vitamin $\mathrm{K}$ (Konakion) intravenøst gis derfor i tillegg (7.).

Ved mekanisk hjerteventil bør man være forsiktig med reversering på grunn av fare for ventiltrombose.

\section{DIREKTEVIRKENDE PERORALE ANTIKOAGULASJONSMIDLER}

Ved hjerneblødning under pågående behandling med DOAK-midler foretrekkes spesifikk antidot hvis tilgjengelig fremfor andre reverseringsstrategier.

Faktor IIa (trombin)-hemmer. Idarusizumab (Praxbind) er et monoklonalt antistoff som gir umiddelbar og fullstendig reversering av virkningen til trombinhemmeren dabigatran (Pradaxa) (16). Det foreligger ingen studier av effekt på hematomekspansjon, funksjon eller mortalitet ved bruk av idarusizumab ved hjerneblødninger, men den farmakologiske

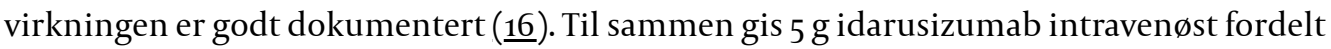
på to doser ( $50 \mathrm{ml}$ bolusinfusjon med $2,5 \mathrm{mg}$ idarusizumab gis over 5-10 minutter med maksimalt 15 minutters mellomrom) (무).

Faktor Xa-hemmere. Andeksanet alfa (Ondexxya) er en rekombinant inaktiv form av faktor Xa som reduserer/opphever den antikoagulerende effekten av faktor Xa-hemmerne apiksaban (Eliquis), edoksaban (Lixiana) og rivaroksaban (Xarelto) (17.). Andeksanet alfa har til sammenlikning med idarusizumab et noe langsommere anslag og har ikke vist varig reversering. Etter noen timer taper andeksanet alfa effekt og faktor Xa-hemmingen øker igjen (17.). Foreløpig er andeksanet alfa ikke tilgjengelig på det norske markedet. 
Ved fravcer av spesifikk antidot. Dersom spesifikk antidot ikke er tilgjengelig, kan protrombinkompleks (50 IE $/ \mathrm{kg}$ ) brukes for å reversere antikoagulasjonseffekten av de direktevirkende perorale antikoagulasjonsmidlene (7.). Vi kjenner ikke til randomiserte kontrollerte studier der man har undersøkt effekten av protrombinkompleks ved hjerneblødning under pågående DOAK-behandling. Observasjonsstudier har ikke vist effekt av protrombinkompleks på hematomekspansjon, funksjon eller mortalitet, men protrombinkompleks har vist seg å kunne normalisere koagulasjonstester $(\underline{18-20})$. Til tross for svært tynt kunnskapsgrunnlag bør man ved akutt hjerneblødning vurdere bruk av protrombinkompleks i tilfeller der spesifikk antidot ikke er tilgjengelig (7.). Dosen protrombinkompleks som skal til for å oppnå reversering av antikoagulasjonseffekten, varierer mellom ulike DOAK-midler, men en dose på $50 \mathrm{IE} / \mathrm{kg}$ vil uansett være tilstrekkelig $(\underline{20-22})$.

Ved blødning under behandling med DOAK-midler er aktivert protrombinkompleks (FEIBA) blitt foreslått som alternativ til protrombinkompleks, spesielt ved trombinhemmeren dabigatran (23). Enkelte studier har vist redusert effekt av

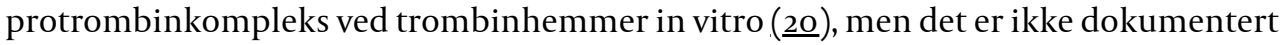
forskjeller mellom protrombinkompleks og aktivert protrombinkompleks i kliniske studier.

UFRAKSJONERT HEPARIN OG LAVMOLEKYLAERE HEPARINER

Ufraksjonert heparin og lavmolekylære hepariner (Klexane, Fragmin) binder og aktiverer antitrombin, som igjen hemmer koagulasjonsfaktorene Xa og IIa (trombin)(figur 1). Lavmolekylære hepariner har størst hemmende effekt på faktor Xa, men hemmer i mindre, men varierende grad også trombin.

Protamin (Protaminsulfat) brukes til å nøytralisere effekten av både ufraksjonert og lavmolekylært heparin. Protamin nøytraliserer all anti-IIa-aktivitet, men kun om lag $50 \%$ av

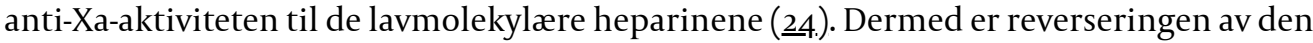
antikoagulerende effekten ufullstendig. Allikevel er det dokumentert at protamin ved lavmolekylære hepariner bedrer hemostasen (25). Vi kjenner ikke til studier der man har undersøkt effekten av protamin ved intrakranial blødning under behandling med ufraksjonert heparin $(\underline{26})$. Protamin brukes ved alvorlige og livstruende blødninger i dosering på henholdsvis $50 \mathrm{mg}$ per 1 ooo IE (ved ufraksjonert heparin) og $10 \mathrm{mg}$ per 1 ooo IE (ved lavmolekylært heparin) og gis som langsom intravenøs infusjon (maks $50 \mathrm{mg} / 10 \mathrm{~min}$ ) for å unngå hypotensjon (27.).

IKKE TIL RUTINEMESSIG BRUK

Rekombinant aktivert faktor VII og traneksamsyre (Cyklokapron) har ikke dokumentert effekt ved hjerneblødning som oppstår under pågående antikoagulasjonsbehandling (7.).

\section{Diskusjon}

Det er ikke dokumentert i randomiserte kontrollerte studier at reverserende behandling bedrer prognosen ved hjerneblødning under behandling med antikoagulerende legemidler. Det er allikevel grunn til å tro at rask reversering av den antikoagulerende effekten kan bedre pasientens utfall. Risikoen for uønskede hendelser som tromboser og hyperkoagulabilitet i akuttfasen som følge av reversering er trolig lav $(13,16)$. Derfor er det lite som taler mot reversering ved akutt hjerneblødning. Visse situasjoner krever derimot særlig varsomhet, slik som ved mekanisk hjerteventil. Hos disse pasientene må den potensielle nytten ved bruk av reverserende behandling vurderes nøye opp imot blødningens alvorlighetsgrad, type hjerteventil og risiko for ventiltrombose. Behandlingen bør skje i samråd med hematolog, slaglege eller kardiolog med relevant erfaring.

Vi tror enkle behandlingsalgoritmer bidrar til rask og mer effektiv akuttbehandling og har derfor foreslått faste doser for hver preparatgruppe. Våre forslag kan medføre at dosen for reverserende behandling er noe høyere enn nødvendig for visse indikasjoner og preparater, 
men uansett innenfor angitt referanseområde for de ulike medikamentene.

Doseringsforslagene vil gi en reversering av den antikoagulerende effekten uavhengig av dose og siste inntak av det antikoagulerende legemiddelet.

De omtalte reverserende medikamentene har til dels høy innkjøpspris. Hos pasienter med svært dårlig prognose, der reverserende behandling trolig vil ha liten betydning for det kliniske utfallet, bør man derfor vurdere indikasjon opp mot nytte. I situasjoner med lang tid fra blødningsiktus til innleggelse bør behandlingen tilpasses størrelsen og lokalisasjonen til hjerneblødningen, koagulasjonstester og tid gått fra siste inntak av

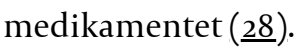

Det er derimot ikke unders $ø$ kt og foreligger ingen enhetlig konsensus rundt tidsvinduet for reverserende behandling. For blodtrykkssenkende behandling ved hjerneblødning er det dokumentert effekt hvis behandlingen starter innen seks timer etter iktus og videreføres det første døgnet (29). Siden fare for reblødning og hematomekspansjon er størst det første døgnet etter iktus (30,31), vil vi foreslå at behandlingen initieres så raskt som mulig hos pasienter med ukjent iktus eller debut siste 24 timer. Senere i forløpet kan man tillate seg å vente på tilleggsinformasjon som er nødvendig for dosetilpasning av reverserende legemiddel (INR-verdi for vitamin K-antagonist, kroppsvekt ved DOAKmidler, administrert dose for lavmolekylære hepariner). Direktevirkende perorale antikoagulasjonsmidler og hepariner, spesielt ufraksjonert heparin, har svært kort halveringstid (fra 30 minutter til 2 timer), og etter fem halveringstider har legemiddelet ikke lenger farmakologisk effekt. Det vil da ikke være behov for reverserende behandling.

\section{KONKLUSJON}

Til tross for begrenset kunnskapsgrunnlag bør man ved akutte hjerneblødninger som hovedregel forsøke å raskt reversere effekten av antikoagulasjonsbehandling. Spesifikk antidot foretrekkes hvis tilgjengelig.

Artikkelen er fagfellevurdert.

\section{LITTERATUR}

1. Loewen P, Dahri K. Risk of bleeding with oral anticoagulants: an updated systematic review and performance analysis of clinical prediction rules. Ann Hematol 2011; 90: 1191-200. [PubMed] [CrossRef]

2. Grundtvig J, Ovesen C, Havsteen I et al. Trends in incidence of oral anticoagulant-related intracerebral hemorrhage and sales of oral anticoagulants in Capital Region of Denmark 2010-2017. Eur Stroke J 2021; 6: 143-50. [PubMed][CrossRef]

3. Steiner T, Weitz JI, Veltkamp R. Anticoagulant-associated intracranial hemorrhage in the era of reversal agents. Stroke 2017; 48: 1432-7. [PubMed][CrossRef]

4. Gulati S, Solheim O, Carlsen SM et al. Risk of intracranial hemorrhage (RICH) in users of oral antithrombotic drugs: Nationwide pharmacoepidemiological study. PLoS One 2018; 13: e0202575. [PubMed][CrossRef]

5. Kjerpeseth LJ, Igland J, Selmer R et al. Prevalence and incidence rates of atrial fibrillation in Norway 2004-2014. Heart 2021; 107: 201-7. [PubMed][CrossRef]

6. Wolf PA, Abbott RD, Kannel WB. Atrial fibrillation as an independent risk factor for stroke: the Framingham Study. Stroke 1991; 22: 983-8. [PubMed][CrossRef]

7. Christensen H, Cordonnier C, Kõrv J et al. European Stroke Organisation Guideline on reversal of oral anticoagulants in acute intracerebral haemorrhage. Eur Stroke J 2019; 4: 294-306. [PubMed] [CrossRef]

8. Berg CL, Olsen K, Sakshaug S. Reseptregisteret 2014-2018. Legemiddelstatistikk 2019:2. Oslo: Folkehelseinstitutet, 2019. 
https://www.fhi.no/contentassets/4df2902e8492453bb22c219bf69d8f71/191303_legemiddelstatistikk201 9.pdf Lest 30.5.2021.

9. Fjærtoft H, Skogseth-Stephani R, Indredavik B et al. Norsk hjerneslagsregister. Årsrapport 2019. Trondheim: St. Olavs hospital, 2019.

https://www.kvalitetsregistre.no/sites/default/files/1_arsrapport_2019_norsk_hjerneslagregister_just ert_21.10.2020.pdf Lest 30.5.2021.

10. Ovesen C, Christensen AF, Krieger DW et al. Time course of early postadmission hematoma expansion in spontaneous intracerebral hemorrhage. Stroke 2014; 45: 994-9. [PubMed][CrossRef]

11. Hemphill JC, Greenberg SM, Anderson CS et al. Guidelines for the Management of Spontaneous Intracerebral Hemorrhage: A Guideline for Healthcare Professionals From the American Heart Association/American Stroke Association. Stroke 2015; 46: 2032-6o. [PubMed][CrossRef]

12. Franchini M, Lippi G. Prothrombin complex concentrates: an update. Blood Transfus 2010; 8: 14954. [PubMed]

13. Steiner T, Poli S, Griebe M et al. Fresh frozen plasma versus prothrombin complex concentrate in patients with intracranial haemorrhage related to vitamin Kantagonists (INCH): a randomised trial. Lancet Neurol 2016; 15:566-73. [PubMed][CrossRef]

14. Sarode R, Milling T], Refaai MA et al. Efficacy and safety of a 4 -factor prothrombin complex concentrate in patients on vitamin $K$ antagonists presenting with major bleeding: a randomized, plasma-controlled, phase IIIb study. Circulation 2013; 128: 1234-43. [PubMed][CrossRef]

15. Yasaka M, Sakata T, Minematsu K et al. Correction of INR by prothrombin complex concentrate and vitamin $\mathrm{K}$ in patients with warfarin related hemorrhagic complication. Thromb Res 2002; 108: 2530. [PubMed][CrossRef]

16. Pollack CV, Reilly PA, Eikelboom J et al. Idarucizumab for dabigatran reversal. N Engl J Med 2015; 373: 511-20. [PubMed][CrossRef]

17. Connolly SJ, Crowther M, Eikelboom JW et al. Full study report of andexanet alfa for bleeding associated with factor Xa inhibitors. N Engl J Med 2019;380: 1326-35. [PubMed][CrossRef]

18. Gerner ST, Kuramatsu JB, Sembill JA et al. Association of prothrombin complex concentrate administration and hematoma enlargement in non-vitamin K antagonist oral anticoagulant-related intracerebral hemorrhage. Ann Neurol 2018; 83:186-96. [PubMed][CrossRef]

19. Purrucker JC, Haas K, Rizos T et al. Early clinical and radiological course, management, and outcome of intracerebral hemorrhage related to new oral anticoagulants. JAMA Neurol 2016; 73:16977. [PubMed][CrossRef]

20. Eerenberg ES, Kamphuisen PW, Sijpkens MK et al. Reversal of rivaroxaban and dabigatran by prothrombin complex concentrate: a randomized, placebo-controlled, crossover study in healthy subjects. Circulation 2011; 124: 1573-9. [PubMed][CrossRef]

21. Cheung YW, Barco S, Hutten BA et al. In vivo increase in thrombin generation by four-factor prothrombin complex concentrate in apixaban-treated healthy volunteers. J Thromb Haemost 2015; 13:1799-805. [PubMed][CrossRef]

22. Zahir H, Brown KS, Vandell AG et al. Edoxaban effects on bleeding following punch biopsy and reversal by a 4 -factor prothrombin complex concentrate. Circulation 2015; 131: 82-90. [PubMed] [CrossRef]

23. Lazo-Langner A, Lang ES, Douketis J. Clinical review: Clinical management of new oral anticoagulants: a structured review with emphasis on the reversal of bleeding complications. Crit Care 2013; 17: 230. [PubMed][CrossRef]

24. Gatt A, van Veen JJ, Woolley AM et al. Thrombin generation assays are superior to traditional tests in assessing anticoagulation reversal in vitro. Thromb Haemost 2008; 100:350-5. [PubMed][CrossRef]

25. Harenberg J, Siegele M, Dempfle CE et al. Protamine neutralization of the release of tissue factor pathway inhibitor activity by heparins. Thromb Haemost 1993; 70: 942-5. [PubMed][CrossRef]

26. Frontera JA, Lewin JJ, Rabinstein AA et al. Guideline for reversal of antithrombotics in intracranial hemorrhage: A statement for healthcare professionals from the Neurocritical Care Society and Society of Critical Care Medicine. Neurocrit Care 2016; 24: 6-46. [PubMed][CrossRef]

27. Parkin TW, Kvale WF. Neutralization of the anticoagulant effects of heparin with protamine (salmine). Am Heart J 1949; 37:333-42. [PubMed][CrossRef]

28. Paroutoglou K, Parry-Jones AR. Hyperacute management of intracerebral haemorrhage. Clin Med (Lond) 2018; 18 (suppl 2): s9-12. [PubMed][CrossRef]

29. Sandset EC, Anderson CS, Bath PM et al. European Stroke Organisation (ESO) guidelines on blood pressure management in acute ischaemic stroke and intracerebral haemorrhage. Eur Stroke J 2021; 6: 23969873211012133. [CrossRef] 
30. Al-Shahi Salman R, Frantzias J, Lee RJ et al. Absolute risk and predictors of the growth of acute spontaneous intracerebral haemorrhage: a systematic review and meta-analysis of individual patient data. Lancet Neurol 2018; 17: 885-94. [PubMed][CrossRef]

31. Kuramatsu JB, Gerner ST, Schellinger PD et al. Anticoagulant reversal, blood pressure levels, and anticoagulant resumption in patients with anticoagulation-related intracerebral hemorrhage. JAMA 2015; 313: 824-36. [PubMed][CrossRef]

Publisert: 5. oktober 2021. Tidsskr Nor Legeforen. DOI: 10.4045/tidsskr.21.0063

Mottatt 22.1.2021, første revisjon innsendt 15.4.2021, godkjent 30.5.2021.

Publisert under åpen tilgang CC BY-ND. Lastet ned fra tidsskriftet.no 26. april 2023. 